\title{
Oncolytic virotherapy in veterinary medicine: current status and future prospects for canine patients
}

\author{
Sandeep S Patil ${ }^{1 \dagger}$, Ivaylo Gentschev ${ }^{1,2+}{ }^{+}$, Ingo Nolte ${ }^{3}$, Gregory Ogilvie ${ }^{4,5}$ and Aladar A Szalay ${ }^{1,2,5,6,7^{*}}$
}

\begin{abstract}
Oncolytic viruses refer to those that are able to eliminate malignancies by direct targeting and lysis of cancer cells, leaving non-cancerous tissues unharmed. Several oncolytic viruses including adenovirus strains, canine distemper virus and vaccinia virus strains have been used for canine cancer therapy in preclinical studies. However, in contrast to human studies, clinical trials with oncolytic viruses for canine cancer patients have not been reported. An 'ideal' virus has yet to be identified. This review is focused on the prospective use of oncolytic viruses in the treatment of canine tumors - a knowledge that will undoubtedly contribute to the development of oncolytic viral agents for canine cancer therapy in the future.
\end{abstract}

Keywords: cancer, canine cancer therapy, oncolytic virus, oncolysis, target molecule, combination therapy

\section{Introduction}

Cancer is the most common cause of natural death in dogs and endemic in both developed and developing countries [1,2]. Incidence of cancer ranges from 1 to $2 \%$ in the canine population and currently accounts for about half of the deaths in dogs older than 10 years $[1,3]$. The major treatment options for canine cancers include surgery, radiation therapy, chemotherapy, hyperthermia and photodynamic therapy. As the standard therapy is usually palliative in canine cancer, there is an excellent opportunity to evaluate alternative approaches.

A promising therapeutic approach is the oncolytic virotherapy. Oncolytic viruses selectively infect, replicate and kill cancer cells, while leaving healthy cells intact. Evidence that viruses may be useful in the eradication of cancer has existed since the early twentieth century $[4,5]$. These early discoveries have led to the testing of several viruses against cancers in both pre-clinical and clinical settings during the 1950s and 1960s [6]. Alice Moore was the first scientist to test oncolytic

\footnotetext{
* Correspondence: aaszalay@genelux.com

† Contributed equally

'Department of Biochemistry, University of Wuerzburg, D-97074 Wuerzburg, Germany

Full list of author information is available at the end of the article
}

virotherapy in an animal model. Working with Russian Far East encephalitis virus, complete regression was achieved in some cases of mouse sarcoma 180 - the first animal model to demonstrate full regression through viral oncolysis [7]. However, during the last 15 years numerous reports have confirmed that intratumorally or systemically delivered viruses such as Newcastle disease virus (NDV) [8], reovirus [9], lentivirus [10] herpes simplex virus (HSV) [11], enterovirus [12], Sindbis virus [13], Semliki Forest virus [14] Seneca Valley virus [15], adenovirus [16], vaccinia virus [17], myxoma [18] and raccoonpox virus [19] could display an antitumor activity in different animal models (for more detailed list of oncolytic viruses readers are directed to [20-22]). Several oncolytic virus (OV) platforms (herpes simplex virus, vaccinia virus, Seneca valley virus and reovirus) are currently in or entering Phase III human clinical trials. In addition, in China the oncolytic adenovirus H101 has been approved in the treatment of human patients with head and neck cancer since 2005 [23].

However, currently the use of oncolytic virotherapy in veterinary medicine is far from reality and promising laboratory results have to be translated into improved clinical outcomes. This review describes the most common classes of oncolytic viruses for canine cancer therapy, and focuses on ways in which these viruses may be
C Biomed Central

() 2012 Patil et al; licensee BioMed Central Ltd. This is an Open Access article distributed under the terms of the Creative Commons Attribution License (http://creativecommons.org/licenses/by/2.0), which permits unrestricted use, distribution, and reproduction in any medium, provided the original work is properly cited. 
manipulated in order to target, enhance and exploit their cytolytic properties for treatment of canine cancer.

\section{Oncolytic Virotherapy for Canine Cancer}

Oncolytic viruses such as various human and canine adenoviruses, canine distemper virus (CDV) and vaccinia virus strains have been preclinically tested for canine cancer therapy.

Adenoviruses are medium-sized (90-100 nm), nonenveloped icosohedral viruses containing double-stranded DNA. They are well characterised for oncolytic therapy in humans and have the ability to infect a broad range of cells cross-species [24,25]. These viruses are restricted to cancer cells at the replication level and hence called conditionally replicating adenoviruses (CRAds). E1A and E1B gene regions of wild type adenovirus are deleted, making virus replication competent in those cells in which $\mathrm{pRb}$ pathway or p53 apoptosis pathway is defective [26]. Moreover, control mechanisms have been added to adenoviruses to ensure cancer cell specificity, and arming the virus with suicide genes has also been explored to improve therapeutic effects [27]. Adenoviruses are also being tested as therapeutic agents for canine cancers. Human adenovirus 5 has been shown to productively replicate in canine osteosarcoma and canine mammary carcinoma cells [28]. Furthermore, canine adenovirus 2 (CAV-2), transcriptionally targeted to canine osteosarcoma cells by inserting osteocalcin promoter, was tested as therapeutic agent for canine osteosarcoma. As this promoter is active only in osteosarcoma cells and not active in other canine non neoplastic cells, CAV-2 with osteocalcin promoter showed restricted replication in canine osteosarcoma cells [29]. This modified canine adenovirus killed canine osteosarcoma cells in cell culture and showed therapeutic benefits in xenograft model [30]. Moreover, administration of CAV-2 to normal dogs showed no major signs of virus-associated toxicity [29]. Arming an adenoviral vector has yielded promising results in canine malignant melanoma cases. Intratumoral injections of this adenoviral vector with CD40 ligand (AdCD40L) revealed inhibition of tumor progression and metastasis in two canine malignant melanoma cases. Also, injections of AdCD40L were safe and no signs of systemic toxicity were observed in canine patients throughout the treatment period [31]. Extension of such studies to clinical trials in the canine population will likely provide better understanding of the oncolytic properties, safety, and therapeutic efficiency of adenoviruses.

Canine distemper virus (CDV) is an enveloped virus with a single stranded RNA genome belonging to the family paramyxoviridae [32]. It is a morbillivirus and possesses many common features with human Measles virus (MV) including its clinical outcomes [33]. Clinical consequences of CDV and MV include profound immune suppression and lymphopenia. Interestingly, regression of Hodgkin's disease was observed in children after concurrent MV infection [34,35] which prompted consideration of the use of attenuated CDV for treatment of canine lymphoma. Moreover, CDV binds to a cellular receptor, Signalling Lymphocyte Activation Molecule (SLAM or CD150) [36,37]. Canine lymphoid cell lines and $\mathrm{B}$ and $\mathrm{T}$ lymphocytes established from dogs with lymphoma have been shown to express CD150 receptors. Attenuated CDV has been tested for oncolytic property in the lymphoma cells and was able to infect and induce apoptosis in these cells [33]. It may therefore be used to treat canine lymphoma patients.

In addition, several preclinical and clinical studies with vaccinia virus (VACV) helped to determine its oncolytic property. VACV is a member of the poxvirus family characterised by double stranded DNA genome [38,39]. It was the first widely used vaccine (in over 200 million people) resulting in eradication of smallpox worldwide, and therefore much is known about its safety profile [40]. Two oncolytic vaccinia virus strains, namely JX594. (Jennerex Biotherapeutics, Inc. USA) and GLV-1h68 (Genelux Corporation, USA), have shown promising preclinical data and are now undergoing clinical trials in humans $[17,41,42]$. The JX594 construct is based on a thymidine kinase $(t k)$ gene-deleted strain derived from the Wyeth strain and expresses GM-CSF and beta-galactosidase (LacZ) [43]. GLV-1h68 (denominated as GLONC1 when produced under GMP conditions) was developed on the base of the Lister strain and carries the gene sequences for a fusion protein of Renilla luciferase and Green Fluorescent Protein (Ruc-GFP), LacZ and beta-glucuronidase (GusA) [17]. In addition, GLV$1 \mathrm{~h} 68$ has been proposed for the treatment of canine mammary adenoma and carcinoma $[44,45]$. The effect of this virus was studied in vitro in the canine mammary carcinoma cell line MTH52c and canine mammary adenoma cell line ZMTH3 and in xenograft models in nude mice. These studies revealed that GLV-1h68 could efficiently infect, replicate in and destroy canine mammary carcinoma MTH52c cells and canine mammary adenoma ZMTH3 cells in culture. Furthermore, in both cases, significant inhibition of tumor growth and damage of tumor tissues was observed after systemic administration of GLV-1h68 in tumor bearing nude mice $[44,45]$. Additionally, the opportunity to localize GLV-1h68 viruses via optical imaging might be utilized in metastasis detection [46]. Moreover, the oncolytic vaccinia virus strain LIVP 1.1.1 efficiently kills canine soft tissue sarcoma cells (Gentschev I et. al., submitted). In this very recent study, a systemic administration of LIVP 1.1.1 virus, a new variant isolated from the wild-type LIVP strain (Chen et. al, unpublished 
data), led to significant growth inhibition and regression of the tumors in a canine sarcoma xenograft mouse model (Gentschev I et. al submitted). The LIVP 1.1.1 mediated therapy was further shown to be sufficient for long-term survival of sarcoma bearing mice and resulted in almost complete tumor regression.

Other poxviruses have also been explored as oncolytic agents for canine tumors. Pre-clinical studies with recombinant canary pox viruses (ALVAC) expressing interleukin 2 have shown the utility of these vectors in promoting anti-tumor activity [47]. Based upon these results, the effect of ALVAC was also analyzed clinically in canine cancer patients. Intratumoral administration of this recombinant poxvirus in dogs with melanoma revealed localized distribution of virus into tumor tissue [48]. Moreover, an ALVAC vaccine against canine distemper virus (RECOMBITEK rDistemper, Merial, USA), has been approved by the USDA and has been demonstrated to be safe and effective in preventing disease in practical field use. However, there are no data regarding the anti-tumor efficacy of ALVAC in canine patients. For a more detailed overview, the characteristics of several oncolytic viruses are listed in Table 1.

\section{Current and Future Challenges of Oncolytic Viral therapy for Canine Cancers}

Despite encouraging progress in the field of oncolytic viral therapy, several limitations remain in the development of an ideal OV including selective targeting of OVs to tumor tissue, relatively poor virus-spread throughout solid tumor tissue, inefficient viral replication in immune-competent hosts and disadvantageous ratio between anti-viral and anti-tumoral immunity. Several strategies to overcome these limitations are currently being investigated. The major strategies include the improvement of existing oncolytic vector systems or using combinations of oncolytic viruses with existing clinical methods or agents for synergistic and/or additive anti-tumor responses. Oncolytic virotherapy for canine cancers is still in its infancy; however, exciting developments in this pioneering approach are expected. This novel therapy has limitations which need to be addressed to improve efficacy, safety and clinical applicability. An overview of some of the problems and solutions is described here.

\subsection{Selective targeting of oncolytic virus to tumor tissue}

A major caveat for the widespread clinical use of virotherapy in canine cancer is to ensure that viruses do not harm normal cells. Certain viruses like NDV, reovirus, vesicular stomatitis virus (VSV), measles virus and others have natural tumor tropism [49-52]. However, better understanding of molecular events of virus-cell interactions in recent years has allowed for the design of genetically engineered viruses that target selected molecules or signalling pathways such as p16, p21 p53, IFN pathway, PTEN, EGFR, VEGFR, STAT3, HSP70, antiapoptosis or hypoxia. Adenoviruses and vaccinia viruses are directed to human cancer cells by taking advantage of these defective pathways. Adenoviruses are designed

Table 1 Oncolytic viruses for canine cancer therapy

\begin{tabular}{|c|c|c|c|}
\hline Virus & $\begin{array}{l}\text { Strains/ } \\
\text { ref. }\end{array}$ & Advantages & Disadvantages \\
\hline Adenovirus & $\begin{array}{l}\text { CAV-1 } \\
{[30]} \\
\text { CAV-2 } \\
{[29]}\end{array}$ & $\begin{array}{l}\text { Infection of both dividing and non dividing cells. } \\
\text { High viral titres in tumor tissue. } \\
\text { Induction of immune response. } \\
\text { Efficient gene transfer. }\end{array}$ & $\begin{array}{l}\text { Pre-existing immunity in canine } \\
\text { population. } \\
\text { Small insert capacity. }\end{array}$ \\
\hline $\begin{array}{l}\text { Canine } \\
\text { Distemper } \\
\text { Virus }\end{array}$ & CDV [33] & $\begin{array}{l}\text { Natural tumor tropism as cellular receptor for entry CD46 is expressed on tumor } \\
\text { cells. } \\
\text { Good safety records as included in vaccine schedule of canines. }\end{array}$ & Only lymphoma therapy data \\
\hline \multirow[t]{2}{*}{$\begin{array}{c}\text { Vaccinia } \\
\text { Virus strains }\end{array}$} & $\begin{array}{c}\text { GLV- } \\
1 \mathrm{~h} 68 \\
{[44,45]}\end{array}$ & $\begin{array}{c}\text { Broad host range. } \\
\text { Attenuated by three insertion cassettes. } \\
\text { Large recombinant gene capacity. } \\
\text { Efficient gene transfer and expression. } \\
\text { No chance for integration of viral genome in to host. }\end{array}$ & $\begin{array}{l}\text { Induction of virus-mediated immune } \\
\text { response }\end{array}$ \\
\hline & LIVP & $\begin{array}{l}\text { Attenuated by natural mutation in thymidine kinase (tk) gene. } \\
\text { Safety of virus is well known. } \\
\text { Broad host range. } \\
\text { Replication in host cytoplasm only, no chance for integration of viral genome in } \\
\text { to host. } \\
\text { Insertion of largest DNA fragment (about } 25 \mathrm{kBps} \text { ) for gene therapy. }\end{array}$ & $\begin{array}{l}\text { Only tested for canine soft tissue } \\
\text { sarcoma. }\end{array}$ \\
\hline $\begin{array}{l}\text { Canary Pox } \\
\text { virus }\end{array}$ & $\begin{array}{l}\text { ALVAC } \\
{[47]}\end{array}$ & $\begin{array}{c}\text { Producing an immune response without any adjuvant. } \\
\text { Approved by the USDA as a vaccine against canine distemper virus (RECOMBITEK } \\
\text { canine distemper) }\end{array}$ & $\begin{array}{c}\text { Protection against canine distemper } \\
\text { virus only }\end{array}$ \\
\hline
\end{tabular}

Abbreviations: CAV-1: Canine adenovirus - 1, CAV-2: Canine adenovirus - 2, CDV: Canine distemper virus, LIVP: Lister strain of Vaccinia virus, ALVAC: Recombinant canarypox virus, GLV-1h68: Recombinant Vaccinia virus by Genelux Corporation USA. 
to target human cancer cells mutated for tumor suppressor protein $\mathrm{p} 53$. The viral protein encoded by the E1 region of wild type adenovirus binds and inactivates p53, allowing replication of virus in normal cells [53]. Because tumor cells lacking functional p53 gene are unable to suppress replication of mutant adenoviruses, E1 gene-deleted adenoviruses have diminished ability to replicate in normal cell and preserved replication in neoplastic cells [26]. Canine p53 family proteins have biological activities similar to their human counterparts [54], with more than $85 \%$ gene sequence similarity. In addition, p53 mutations in canine tumors are located within the exons similar to those reported in human genes [55], and mutations in conserved domains of p53 appear to play a significant role in mammary carcinogenesis in both humans and dogs [56]. Like in human tumors, the p53 gene is mutated in several canine cancers, including osteosarcoma [57], mammary tumors [58] and gastric carcinoma [59]. All these points suggest that canine and human p53 protein has similar biological functions which can be helpful in designing better therapeutic modalities against canine cancer. Thus, oncolytic viruses, especially adenovirus, can specifically be targeted to canine cancer cells by taking advantage of the defective p53 pathway. In another example, VACV mutants with deletions in the thymidine kinase gene $(t k)$ and/or vaccinia growth factor gene (VGF) are well advanced in pre-clinical and clinical studies for human cancers $[60,61]$. These mutants grow selectively in cancer cells with high levels of cellular thymidine kinase (TK), and constitutively activated EGFR/Ras pathway signalling complements the loss of the viral gene products [62]. Moreover, tumor cells release the TK enzyme to the circulation, probably due to disruption of dead or dying tumor cells [63]. Increased serum TK activity was observed in various canine malignancies like lymphoma [63,64], leukemia [65] and hemangiosarcoma [66], suggesting a possible target for directing Vaccinia virus to tumor tissue. In addition, higher expression of EGFR in mammary [67], glioma [68], hepatocellular carcinoma [69] and malignant epithelial nasal tumors [70] of canine origin closely parallels that of human tumors of the same type and histologic grade. High levels of EGFR and TK in various canine cancers could be basis of enhancing replication of Vaccinia virus in canine cancer cells.

To further enhance the tropism of vaccinia virus to human cancer cells, Kirn and colleagues deleted the B18R gene, which encodes a protein that neutralizes type I interferons (IFNs), producing a highly tumor-specific oncolytic vaccinia virus [71]. IFNs are a group of secreted cytokines, which exert pleiotropic effects on important cell functions, including cell proliferation and modulation of the immune system $[72,73]$. The IFN system also mediates the first line of cellular anti-viral response. Interestingly, about $70-75 \%$ of the cancer cells are defective in the IFN pathway [74]. Mutation in B18R gene allows the vaccinia virus to selectively infect (cancer) cells with defects in their IFN responses but not normal cells with intact IFN responses. In this context, canine cancer cells with defects of the IFN system may be optimal targets for OVs, which exploit such defects to support their own replication.

Numerous other strategies such as transductional targeting, which use conditionally replicating viruses e.g. canine adenovirus [30] and transcriptional targeting, which includes use of specific promoters [29], may also aid in selective targeting of oncolytic viruses to cancer cells.

\subsection{Spread of oncolytic viruses throughout the tumor mass}

Another challenge for effective oncolytic virotherapy is the relatively poor penetration of the virus throughout solid tumor masses. As observed in human cancers, the slow spread of virus in solid tumors can be limiting and determines the outcome of therapy [75]. The slow viral spread within solid tumors might relate to the relatively large size of OVs (e.g. around $200 \mathrm{~nm}$ of vaccinia virus and around $90 \mathrm{~nm}$ for adenovirus). Recently, Altomonte et al. showed that a single amino acid modification in the fusion protein of NDV greatly improved the fusogenicity of a recombinant virus, thereby resulting in enhanced tumor cell killing through the formation of large multi-nucleated syncytia and spread of the virus throughout the tumor mass [76].

The intratumoral spread and efficacy of OVs were also improved by protease or hyaluronidase mediated digestion of tumor extracellular matrix (ECM) [77-82]. Structural components of tumor ECM, such as collagens and proteoglycans, have been shown to hinder distribution of large therapeutic molecules and viruses [82]. Therefore, the degradation of extracellular matrix with $\mathrm{OV}$ expressing matrix proteases and collagenases may be a useful strategy to achieve anticancer effects in both humans and dogs.

\subsection{Optimization of viral replication in immune- competent hosts}

Immune responses against viruses presumably limit ongoing viral replication in immunocompetent dogs. In this context, a high level of pre-existing immunity to parental viruses in canine populations might limit the use of oncolytic viruses for cancer therapy. The role of virus-neutralizing antibodies following intravenous administration remains to be determined. Use of unrelated viruses from different hosts, such as vaccinia for dog cancers, may solve the problem of pre-existing 
immunity. However, carrier cell based therapy also provided promising results to escape pre-existing immunity [83]. In this regard, several types of cells, such as immune cells [84-86], stem cells $[84,87,88]$ and tumor cells $[89,90]$ were successfully utilized as carriers of oncolytic viruses to tumors. Specific delivery to tumors and escape of the pre-existing antiviral immunity increased the effective local viral dose in the tumor tissue and thus enhanced the oncolytic effects [90-92]. However, mechanisms for the specific homing of carrier cells to tumors are currently unknown.

In a recent study, canine osteosarcoma cells treated with replication selective canine adenovirus (OCCAV) were used as carrier vehicles for evading pre-existing neutralizing antibodies against adenovirus. Systemic antitumoral activity of OCCAV, even in presence of adenovirus neutralizing antibodies, suggests a promising approach to evade pre-existing immunity against the viral vector [93].

The efficiency of OV replication in tumor bearing immunocompetent dogs may be enhanced by various means such as combination of viro- with chemo- [94] or radiation therapy [95] or the conjunctive use of different oncolytic viruses [96].

\subsection{Enhancing Anti-tumor Immunity and/or Anti-tumor Effects of OVs by Virus-integrated Genes}

Several strategies have been developed to achieve better anti-tumoral immunity and/or anti-tumor effects after OV cancer treatment. One strategy involves the integration of genes encoding either proteins with immunomodulatory functions, such as cytokines or chemokines, or tumor associated antigens (TAA). However, the optimal balance between anti-viral and anti-tumor immune responses is crucial for the success of these cancer therapies in immunocompetent patients.

Another strategy to enhance the OV mediated anticancer activity is targeting the tumor microenvironment with replicating OVs. One promising target here is the tumor neoangiogenesis. Recently, Breitbach and colleges demonstrated that VSV directly infects and destroys tumor vasculature in vivo, leaving the normal vasculature intact [97]. In addition, armed oncolytic viruses can also prevent neoangiogenesis, leading to cancer cell necrosis. Vascular endothelial growth factor (VEGF) is a protein that plays a key role in tumor angiogenesis [98]. Vaccinia virus encoding anti-VEGFR-1 protein decreases neoangiogenesis at the tumor site and inhibits the tumor growth [99]. Furthermore, blocking VEGF has shown enhanced antitumor activity in a human xenograft model where vaccinia virus was armed with antiVEGF antibody [100]. As seen for human tumors, significant expression of VEGF enhanced angiogenesis in canine mammary gland tumors [101]. Also, increased levels of VEGF-2 were observed in canine intracranial meningiomas [102], mammary adenocarcinoma [103], mastocytoma [104], mast cell tumors [105], and soft tissue sarcoma [106]. Expression of VEGF in a variety of canine cancers proves its role in canine tumor angiogenesis. Thus, oncolytic viruses armed with anti-VEGF agents will be a possible therapeutic approach for canine cancers.

Finally, the anticancer activity of OVs may also be improved by expression of prodrug-converting enzymes capable of producing a toxic product within tumor tissue. Recombinant oncolytic viruses have been used to express suicide genes that convert a pro-drug into toxic drug within the tumor. Nitro-reductase enzyme from $E$. coli causes reduction of inactive prodrug CB1954 to promote cell killing in feline cancer cells [107]. Similarly, 5Fluorouracil is a pyrimidine analog widely used in canine cancer chemotherapy. Bacterial and/or yeast cytosine deaminase (CDase) is a well characterized enzyme-prodrug system that converts 5-Fluorocytosine to 5-Fluorouracil which further leads to cell cycle arrest and apoptosis leading to improved antitumor effects [108]. Therefore, OVs armed with nitroreductase or cytosine deaminase gene in combination with prodrugs may synergistically destroy canine cancer cells.

\section{Combination of Oncolytic Viruses with Conventional Cancer Therapy in Dogs}

One way to augment the efficacy of viral oncolysis is to combine genetically engineered replication competent viruses with standard anti-cancer therapies such as chemo- and radiotherapy.

Several pre-clinical and clinical studies have shown that combination of oncolytic viruses and radiation therapy may achieve additional or synergistic anti-tumor effects in in vitro and in vivo studies [109]. The experimental data demonstrated that ionizing radiation may also enhance viral replication and oncolysis within irradiated tumors.

Recently, the combination of oncolytic virotherapy with chemotherapy has shown that use of these two therapies with very distinct anti-tumor mechanisms may also lead to synergistic interactions [110]. Therefore, combination with radiation or chemotherapy may be a key to the optimization of the oncolytic viral therapy in dogs.

\section{Ideal Oncolytic Virus for Canine Cancer Therapy}

Improvement of replicating viral systems for canine cancer treatment is continuously being achieved, and many viruses are potentially useful for targeting canine cancer cells. However, an important question that still raises controversy is "which virus is best"? Several 
characteristics of oncolytic viruses for human cancer treatment have been described earlier [111,112]. There are no major variations as far as characteristics of ideal oncolytic viruses for canine cancer. An ideal oncolytic virus should demonstrate the following characteristics:

1. Efficient, safe and complete destruction of tumor tissue.

2. Selective replication in canine cancer cells.

3. Resistance against pre-existing immunity in canine populations.

4. Eliciting strong immune responses against tumor cells.

5. Propagation-deficient (safe) in immunocompromised patients.

6. Efficient clearance from the body preventing latent or recurrent infection.

7. No integration of viral genome into the canine genome.

8. Easily engineered to express antitumor agents.

9. Large recombinant gene carrying capacity.

10. Cost effectiveness and economy for widespread use in canine cancer patients.

11. Easy to monitor with respect to successful tumor colonization.

Many promising oncolytic viruses are being developed with convincing results in preclinical trials. However, it is unlikely that a virus will possess all the criteria of an 'ideal' oncolytic virus. In our opinion, vaccinia virus and adenovirus strains exhibit several characteristics of an ideal OV and show the most promising results in preclinical studies. In summary, similar to human cancer patients, OVs seem to hold promise in treatment of canine cancer.

\section{Translation of Oncolytic Virotherapy from Dogs to Humans and the Reverse}

Canine cancers share many features in common with human cancers including histological appearance, tumor genetics, molecular targets and response to conventional therapy [113-116]. In both species, tumor initiation and progression is influenced by similar factors like age, nutrition, sex and environmental exposure $[117,118]$. Dogs show as diverse cancers as seen in humans. These similarities are further seen in the development of therapeutics. Furthermore, carcinogenesis and tumor biologic behaviour in dogs have more features in common with humans than with laboratory rodents [119]. Despite evidence of oncolytic virus efficacy in mouse models of cancers, many viruses fail in human trials due to unacceptable toxicity or lack of efficacy [120]. Some strains of oncolytic viruses such as human adenovirus and vaccinia virus in general do not productively replicate in mouse cells. Thus, certain permissive cancer cells are grown in immunocompetent animals to study virus replication [121,122]. However, artificial establishment of these tumors as subcutaneous xenografts raises concern as to how well this model mimics their natural human counterparts. Hence, pet dogs with tumors are necessary models to demonstrate efficacy of OVs for human cancers. An alternative approach may be the use of species specific viruses in their natural host system. For example, application of Canine Adenovirus 2 in osteosarcoma of dog has shown to address the issue of tumor setting, efficient virus replication and oncolysis [30]. In this case, canine osteosarcoma resembles human osteaosarcoma at several levels including histopathology and metastatic behaviour [123]. However, Canine Adenovirus 2 shares similarities with human adenoviruses which are used as oncolytic agents for human osteosarcoma. The data from these studies are more reliable and may be helpful in designing human clinical trials. However, as far as veterinary medicine is concerned, development of oncolytic virotherapy for cancer to heal canine patients is of prime importance. Many of the treatment options used in veterinary medicine resemble protocols used to treat human cancer patients. In addition, public release of nearly $99 \%$ canine genome sequences provided a window of opportunity to expand the scope of comparative oncology. Comparison of canine genome sequences with the human genome suggests that around 19000 genes identified in the dog match to similar or orthologous genes in the human genome [124]. Taking into consideration the value of comparative oncology, data obtained from human clinical trials can be effectively transferred to canines.

\section{Conclusions}

Canine tumors are complex entities that continue to challenge modern veterinary medicine to develop more reliable cancer therapies. The field of oncolytic virotherapy is expanding and viruses continue to hold promise as an effective therapeutic approach for human cancers. Like in humans, oncolytic viruses replicate at the target site and spread within tumors to lyse neoplastic cells leading to decreased tumor burden in dogs. However studies of oncolytic viruses for canine cancer treatment are limited. It is not clear from past studies or from current understandings of potential oncolytic viruses which virus will be 'best' for canine cancer treatment. Nonetheless, preclinical studies with vaccinia and adenovirus for canine cancer therapy provided significant results which need exploration in canine clinical trials. Similarly, the therapeutic transgene expression capacity of these viruses will likely also need to be developed. Armed therapeutic viruses or genetically engineered viruses represent a very appealing tumor targeting 
approach and a novel opportunity to generate agents that could potentially cure canine cancers. Furthermore, studying dogs with cancer is likely to provide valuable information that is distinct from that generated in studies of rodent cancers alone. The importance of this opportunity must therefore be considered for the development of effective oncolytic therapy for canine as well as human cancers patients. It is hoped that collective efforts will contribute to the development of effective and safe viruses for both human and canine cancer therapy.

\section{List of abbreviations used}

CDase: cytosine deaminase; CDV: Canine distemper virus; ECM: extracellular matrix; EGFR: Epidermal Growth Factor Receptor; GM-CSF: Granulocyte Macrophage Colony Stimulating Factor; GusA: beta-glucuronidase; HSP70: Heat Shock Protein 70; HSV: herpes simplex virus; IFNs: interferons; LacZ: beta-galactosidase; Ruc-GFP: Renilla luciferase-green fluorescent protein; LIVP: Lister strain of vaccinia virus; MV: Measles virus; NDV: Newcastle Disease Virus; OV: oncolytic virus; pRb pathway: retinoblastoma protein pathway; PTEN: phosphatase and tensin homologue deleted on chromosome 10; STAT3: Signal Transducer and Activator of Transcription 3 (gene); TAA: tumor associated antigens; $t k$ : thymidine kinase gene; Ras: extracellular signalregulated kinase; USDA: United States Department of Agriculture; VACV: vaccinia virus; VEGF: Vascular endothelial growth factor; VGF: Vaccinia Growth Factor.

\section{Acknowledgements}

We like to thank J. Stritzker, Q. Zhang, N. G. Chen, Y. A. Yu and A. MacNeill for providing unpublished data to the authors and J. Stritzker, D. Haddad and B. Minev for critical reading of the manuscript. The original studies of I. Gentschev, I. Nolte and A.A. Szalay presented in this review were funded by Genelux Corporation, San Diego, USA. S. S. Patil is a graduate fellow and supported by a grant of the German Excellence Initiative to the Graduate School of Life Sciences, University of Wuerzburg. This publication was funded by the German Research Foundation (DFG) and the University of Wuerzburg in the funding programme Open Access Publishing.

\section{Author details \\ 'Department of Biochemistry, University of Wuerzburg, D-97074 Wuerzburg, Germany. ${ }^{2}$ Genelux Corporation, San Diego Science Center, San Diego, California, USA. ${ }^{3}$ Small Animal Clinic, University of Veterinary Medicine, D- 30173 Hannover, Germany. ${ }^{4}$ Angel Care Cancer Center, California Veterinary Specialists, Carlsbad, CA, 92008, USA. ${ }^{5}$ Department of Radiation Oncology, Moores Cancer Center, University of California, San Diego, 3855 Health Sciences Drive \# 0843, La Jolla, CA 92093, USA. ${ }^{6}$ Rudolf Virchow Center for Experimental Biomedicine, University of Wuerzburg, D-97078 Wuerzburg, Germany. ${ }^{7}$ Institute for Molecular Infection Biology, University of Wuerzburg, D-97078 Wuerzburg, Germany.}

\section{Authors' contributions}

SSP and IG critically reviewed the literature for the review. SSP, IG, IN, GO and AAS participated in conceiving the review and writing the manuscript. All the authors read and approved the final manuscript.

\section{Competing interests}

I. Gentschev and A.A. Szalay have interests in developing vaccinia virus as an oncolytic virus with Genelux Corporation, San Diego, USA. This work also was supported in part by grants from the Research and Development Division of Genelux Corporation, San Diego, USA. The funders had no role in study design, data collection and analysis, decision to publish, or preparation of the manuscript.

Received: 13 October 2011 Accepted: 4 January 2012

Published: 4 January 2012

\section{References}

1. Merlo DF, Rossi L, Pellegrino C, Ceppi M, Cardellino U, Capurro C, Ratto A, Sambucco PL, Sestito V, Tanara G, Bocchini V: Cancer incidence in pet dogs: findings of the Animal Tumor Registry of Genoa, Italy. J Vet Intern Med 2008, 22:976-984

2. National Canine Cancer Foundation. [http://www.earethecure.org/].

3. Kelsey JL, Moore AS, Glickman LT: Epidemiologic studies of risk factors for cancer in pet dogs. Epidemiol Rev 1998, 20:204-217.

4. Southam CM, Moore AE: Clinical studies of viruses as antineoplastic agents with particular reference to Egypt 101 virus. Cancer 1952, 5:1025-1034.

5. Sinkovics JG: Viral oncolysates as human tumor vaccines. Int Rev Immunol 1991, 7:259-287

6. Vaha-Koskela MJ, Heikkila JE, Hinkkanen AE: Oncolytic viruses in cancer therapy. Cancer Lett 2007, 254:178-216.

7. Moore AE: The destructive effect of the virus of Russian Far East encephalitis on the transplantable mouse sarcoma 180. Cancer 1949, 2:525-534.

8. Phuangsab A, Lorence RM, Reichard KW, Peeples ME, Walter RJ: Newcastle disease virus therapy of human tumor xenografts: antitumor effects of local or systemic administration. Cancer Lett 2001, 172:27-36.

9. Hirasawa K, Nishikawa SG, Norman KL, Coffey MC, Thompson BG, Yoon CS, Waisman DM, Lee PW: Systemic reovirus therapy of metastatic cancer in immune-competent mice. Cancer Res 2003, 63:348-353.

10. De Palma M, Venneri MA, Naldini L: In vivo targeting of tumor endothelia cells by systemic delivery of lentiviral vectors. Hum Gene Ther 2003, 14:1193-1206.

11. Fu $X$, Zhang $X$ : Delivery of herpes simplex virus vectors through liposome formulation. Mol Ther 2001, 4:447-453.

12. Shafren DR, Au GG, Nguyen T, Newcombe NG, Haley ES, Beagley L, Johansson ES, Hersey P, Barry RD: Systemic therapy of malignant human melanoma tumors by a common cold-producing enterovirus, coxsackievirus a21. Clin Cancer Res 2004, 10:53-60

13. Tseng JC, Levin B, Hurtado A, Yee H, Perez de Castro I, Jimenez M, Shamamian P, Jin R, Novick RP, Pellicer A, Meruelo D: Systemic tumor targeting and killing by Sindbis viral vectors. Nat Biotechnol 2004, 22:70-77.

14. Vaha-Koskela MJ, Kallio JP, Jansson LC, Heikkila JE, Zakhartchenko VA, Kallajoki MA, Kahari VM, Hinkkanen AE: Oncolytic capacity of attenuated replicative semliki forest virus in human melanoma xenografts in severe combined immunodeficient mice. Cancer Res 2006, 66:7185-7194.

15. Reddy PS, Burroughs KD, Hales LM, Ganesh S, Jones BH, Idamakanti N, Hay C, Li SS, Skele KL, Vasko AJ, et al: Seneca Valley virus, a systemically deliverable oncolytic picornavirus, and the treatment of neuroendocrine cancers. I Natl Cancer Inst 2007 99:1623-1633.

16. Dobbelstein M: Replicating adenoviruses in cancer therapy. Curr Top Microbiol Immunol 2004, 273:291-334.

17. Zhang Q, Yu YA, Wang E, Chen N, Danner RL, Munson PJ, Marincola FM, Szalay AA: Eradication of solid human breast tumors in nude mice with an intravenously injected light-emitting oncolytic vaccinia virus. Cancer Res 2007, 67:10038-10046.

18. Lun XQ, Yang WQ, Alain T, Shi ZQ, Muzik H, Barrett JW, McFadden G, John BH, Hamilton MG, Senger DL, Forsyth PA: Myxoma virus is a novel oncolytic virus with significant antitumor activity against experimental human gliomas. Cancer Res 2005, 65:9982-9990.

19. Evgin L, Vaha-Koskela M, Rintoul J, Falls T, Le Boeuf F, Barrett JW, Bell JC, Stanford MM: Potent Oncolytic Activity of Raccoonpox Virus in the Absence of Natural Pathogenicity. Molecular Therapy 2010, 18:896-902.

20. Russell SJ: RNA viruses as virotherapy agents. Cancer Gene Ther 2002 9:961-966.

21. Parato KA, Senger D, Forsyth PA, Bell JC: Recent progress in the battle between oncolytic viruses and tumours. Nat Rev Cancer 2005, 5:965-976.

22. Cattaneo R, Miest $T$, Shashkova EV, Barry MA: Reprogrammed viruses as cancer therapeutics: targeted, armed and shielded. Nat Rev Microbiol 2008, 6:529-540.

23. Garber K: China approves world's first oncolytic virus therapy for cancer treatment. J Natl Cancer Inst 2006, 98:298-300.

24. Nemunaitis J, Cunningham C: Emerging new therapies for chemotherapyresistant cancer using adenoviral vectors. Drug Resist Updat 2002, 5:34-46.

25. Yu W, Fang H: Clinical trials with oncolytic adenovirus in China. Curr Cancer Drug Targets 2007, 7:141-148. 
26. Bischoff JR, Kirn DH, Williams A, Heise C, Horn S, Muna M, Ng L, Nye JA, Sampson-Johannes A, Fattaey A, McCormick F: An adenovirus mutant that replicates selectively in p53-deficient human tumor cells. Science 1996, 274:373-376

27. Liu TC, Wang Y, Hallden G, Brooks G, Francis J, Lemoine NR, Kirn D: Functional interactions of antiapoptotic proteins and tumor necrosis factor in the context of a replication-competent adenovirus. Gene Ther 2005, 12:1333-1346.

28. Ternovoi W, Le LP, Belousova N, Smith BF, Siegal GP, Curiel DT: Productive replication of human adenovirus type 5 in canine cells. J Virol 2005, 79:1308-1311.

29. Smith BF, Curiel DT, Ternovoi W, Borovjagin AV, Baker HJ, Cox N, Siegal GP: Administration of a conditionally replicative oncolytic canine adenovirus in normal dogs. Cancer Biother Radiopharm 2006, 21:601-606.

30. Le LP, Rivera AA, Glasgow JN, Ternovoi W, Wu H, Wang M, Smith BF, Siegal GP, Curiel DT: Infectivity enhancement for adenoviral transduction of canine osteosarcoma cells. Gene Ther 2006, 13:389-399.

31. von Euler H, Sadeghi A, Carlsson B, Rivera P, Loskog A, Segall T, Korsgren O, Totterman TH: Efficient adenovector CD40 ligand immunotherapy of canine malignant melanoma. J Immunother 2008, 31:377-384.

32. International Committee on Taxonomy of Viruses., Van Regenmortel MHV, International Union of Microbiological Societies. Virology Division: Virus taxonomy: classification and nomenclature of viruses: seventh report of the International Committee on Taxonomy of Viruses San Diego: Academic Press; 2000.

33. Suter SE, Chein MB, von Messling V, Yip B, Cattaneo R, Vernau W, Madewell BR, London CA: In vitro canine distemper virus infection of canine lymphoid cells: a prelude to oncolytic therapy for lymphoma. Clin Cancer Res 2005, 11:1579-1587.

34. Bluming AZ, Ziegler JL: Regression of Burkitt's lymphoma in association with measles infection. Lancet 1971, 2:105-106.

35. Gross S: Measles and leukaemia. Lancet 1971, 1:397-398.

36. Tatsuo H, Ono N, Tanaka K, Yanagi Y: SLAM (CDw150) is a cellular receptor for measles virus. Nature 2000, 406:893-897.

37. Tatsuo $H$, Ono N, Yanagi Y: Morbilliviruses use signaling lymphocyte activation molecules (CD150) as cellular receptors. J Virol 2001 75:5842-5850.

38. Shchelkunov SN, Totmenin AV, Babkin IV, Safronov PF, Ryazankina OI, Petrov NA, Gutorov W, Uvarova EA, Mikheev MV, Sisler JR, et al: Human monkeypox and smallpox viruses: genomic comparison. FEBS Lett 2001, 509:66-70.

39. Moss B, Earl PL: Overview of the vaccinia virus expression system. Curr Protoc Protein Sci 2001, Chapter 5, Unit5 11.

40. Fenner F: Smallpox and its eradication. World Health Organization, Geneva 1988.

41. Dranoff G: GM-CSF-based cancer vaccines. Immunol Rev 2002, 188:147-154

42. Clinical Trail Govt Database. [http://clinicaltrialsgov/ct2/show/ NCT00794131]

43. Park BH, Hwang T, Liu TC, Sze DY, Kim JS, Kwon HC, Oh SY, Han SY, Yoon JH, Hong SH, et al: Use of a targeted oncolytic poxvirus, JX-594, in patients with refractory primary or metastatic liver cancer: a phase I trial. Lancet Oncol 2008, 9:533-542.

44. Gentschev I, Ehrig K, Donat U, Hess M, Rudolph S, Chen N, Yu YA, Zhang Q, Bullerdiek J, Nolte I, et al: Significant Growth Inhibition of Canine Mammary Carcinoma Xenografts following Treatment with Oncolytic Vaccinia Virus GLV-1h68. J Oncol 2010, 2010:736907.

45. Gentschev I, Stritzker J, Hofmann E, Weibel S, Yu YA, Chen N, Zhang Q, Bullerdiek J, Nolte I, Szalay AA: Use of an oncolytic vaccinia virus for the treatment of canine breast cancer in nude mice: preclinical development of a therapeutic agent. Cancer Gene Ther 2009, 16:320-328.

46. Kelly KJ, Brader P, Woo Y, Li S, Chen N, Yu YA, Szalay AA, Fong Y: Real-time intraoperative detection of melanoma lymph node metastases using recombinant vaccinia virus GLV-1h68 in an immunocompetent animal model. Int J Cancer 2009, 124:911-918.

47. Perkus ME, Taylor J, Tartaglia J, Pincus S, Kauffman EB, Tine JA, Paoletti E: Live attenuated vaccinia and other poxviruses as delivery systems: public health issues. Ann N Y Acad Sci 1995, 754:222-233.

48. Jourdier TM, Moste C, Bonnet MC, Delisle F, Tafani JP, Devauchelle P, Tartaglia J, Moingeon P: Local immunotherapy of spontaneous feline fibrosarcomas using recombinant poxviruses expressing interleukin 2 (IL2). Gene Ther 2003, 10:2126-2132.
49. Hasegawa K, Nakamura T, Harvey M, Ikeda Y, Oberg A, Figini M, Canevari S, Hartmann LC, Peng KW: The use of a tropism-modified measles virus in folate receptor-targeted virotherapy of ovarian cancer. Clin Cancer Res 2006, 12:6170-6178.

50. Hashiro G, Loh PC, Yau JT: The preferential cytotoxicity of reovirus for certain transformed cell lines. Arch Virol 1977, 54:307-315.

51. Lorence RM, Reichard KW, Katubig BB, Reyes HM, Phuangsab A, Mitchell BR, Cascino CJ, Walter RJ, Peeples ME: Complete regression of human neuroblastoma xenografts in athymic mice after local Newcastle disease virus therapy. J Natl Cancer Inst 1994, 86:1228-1233.

52. Stojdl DF, Lichty B, Knowles S, Marius R, Atkins H, Sonenberg N, Bell JC: Exploiting tumor-specific defects in the interferon pathway with a previously unknown oncolytic virus. Nat Med 2000, 6:821-825.

53. Yew PR, Berk AJ: Inhibition of p53 transactivation required for transformation by adenovirus early 1B protein. Nature 1992, 357:82-85

54. Zhang J, Chen X, Kent MS, Rodriguez CO: Establishment of a dog model for the p53 family pathway and identification of a novel isoform of p21 cyclin-dependent kinase inhibitor. Mol Cancer Res 2009, 7:67-78.

55. Chu LL, Rutteman GR, Kong JM, Ghahremani M, Schmeing M, Misdorp W, van Garderen E, Pelletier J: Genomic organization of the canine p53 gene and its mutational status in canine mammary neoplasia. Breast Cancer Res Treat 1998, 50:11-25.

56. Queiroga FL, Raposo T, Carvalho MI, Prada J, Pires I: Canine mammary tumours as a model to study human breast cancer: most recent findings. In Vivo 2011, 25:455-465.

57. Levine RA, Fleischli MA: Inactivation of p53 and retinoblastoma family pathways in canine osteosarcoma cell lines. Vet Pathol 2000, 37:54-61.

58. Rungsipipat A, Tateyama S, Yamaguchi R, Uchida K, Miyoshi N, Hayashi T: Immunohistochemical analysis of c-yes and c-erbB-2 oncogene products and p53 tumor suppressor protein in canine mammary tumors. J Vet Med Sci 1999, 61:27-32

59. Carrasco V, Canfran S, Rodriguez-Franco F, Benito A, Sainz A, RodriguezBertos A: Canine gastric carcinoma: immunohistochemical expression of cell cycle proteins (p53, p21, and p16) and heat shock proteins (Hsp27 and Hsp70). Vet Pathol 2011, 48:322-329.

60. Kirn DH, Thorne SH: Targeted and armed oncolytic poxviruses: a novel multi-mechanistic therapeutic class for cancer. Nat Rev Cancer 2009, 9:64-71.

61. Liu L, Chavan R, Feinberg MB: Dendritic cells are preferentially targeted among hematolymphocytes by Modified Vaccinia Virus Ankara and play a key role in the induction of virus-specific T cell responses in vivo. BMC Immunol 2008, 9:15.

62. Thorne $\mathrm{SH}$, Contag $\mathrm{CH}$ : Combining immune cell and viral therapy for the treatment of cancer. Cell Mol Life Sci 2007, 64:1449-1451.

63. Nakamura N, Momoi $Y$, Watari $T$, Yoshino $T$, Tsujimoto $H$, Hasegawa A: Plasma thymidine kinase activity in dogs with lymphoma and leukemia. J Vet Med Sci 1997, 59:957-960.

64. von Euler H, Einarsson R, Olsson U, Lagerstedt AS, Eriksson S: Serum thymidine kinase activity in dogs with malignant lymphoma: a potent marker for prognosis and monitoring the disease. J Vet Intern Med 2004, 18:696-702.

65. Von Euler HP, Rivera P, Aronsson AC, Bengtsson C, Hansson LO, Eriksson SK: Monitoring therapy in canine malignant lymphoma and leukemia with serum thymidine kinase 1 activity-evaluation of a new, fully automated non-radiometric assay. Int J Oncol 2009, 34:505-510.

66. Selting KA, Thamm DH: Serum thymidine kinase concentrations in normal versus tumor-bearing dogs. Journal of Veterinary Internal Medicine 2008, 22:704-704.

67. Gama A, Gartner F, Alves A, Schmitt F: Immunohistochemical expression of Epidermal Growth Factor Receptor (EGFR) in canine mammary tissues. Res Vet Sci 2009, 87:432-437.

68. Higgins RJ, Dickinson PJ, LeCouteur RA, Bollen AW, Wang H, Corely LJ, Moore LM, Zang W, Fuller GN: Spontaneous canine gliomas: overexpression of EGFR, PDGFRalpha and IGFBP2 demonstrated by tissue microarray immunophenotyping. J Neurooncol 2010, 98:49-55.

69. Grabarevic Z, Coric M, Seiwerth S, Dzaja P, Artukovic B, Kurilj AG, Beck A, Hohsteter M, Sostaric-Zuckermann IC, Brcic L, Hrstic I: Comparative analysis of hepatocellular carcinoma in men and dogs. Coll Antropol 2009, 33:811-814.

70. Shiomitsu K, Johnson CL, Malarkey DE, Pruitt AF, Thrall DE: Expression of epidermal growth factor receptor and vascular endothelial growth factor 
in malignant canine epithelial nasal tumours. Vet Comp Oncol 2009, 7:106-114.

71. Kirn DH, Wang Y, Le Boeuf F, Bell J, Thorne SH: Targeting of interferonbeta to produce a specific, multi-mechanistic oncolytic vaccinia virus. PLoS Med 2007, 4:e353.

72. Dunn GP, Koebel CM, Schreiber RD: Interferons, immunity and cancer immunoediting. Nat Rev Immunol 2006, 6:836-848.

73. Stetson DB, Medzhitov R: Type I interferons in host defense. Immunity 2006, 25:373-381.

74. Xu L, Rothman P: IFN-gamma represses epsilon germline transcription and subsequently down-regulates switch recombination to epsilon. Int Immunol 1994, 6:515-521.

75. Heise CC, Williams A, Olesch J, Kirn DH: Efficacy of a replicationcompetent adenovirus (ONYX-015) following intratumoral injection: intratumoral spread and distribution effects. Cancer Gene Ther 1999, 6:499-504.

76. Altomonte J, Marozin S, Schmid RM, Ebert O: Engineered newcastle disease virus as an improved oncolytic agent against hepatocellular carcinoma. Mol Ther 2010, 18:275-284.

77. Hong CS, Fellows W, Niranjan A, Alber S, Watkins S, Cohen JB, Glorioso JC, Grandi P: Ectopic matrix metalloproteinase-9 expression in human brain tumor cells enhances oncolytic HSV vector infection. Gene Ther 2010, 17:1200-1205.

78. Ganesh S, Gonzalez Edick M, Idamakanti N, Abramova M, Vanroey M, Robinson M, Yun CO, Jooss K: Relaxin-expressing, fiber chimeric oncolytic adenovirus prolongs survival of tumor-bearing mice. Cancer Res 2007, 67:4399-4407.

79. Guedan S, Rojas JJ, Gros A, Mercade E, Cascallo M, Alemany R: Hyaluronidase expression by an oncolytic adenovirus enhances its intratumoral spread and suppresses tumor growth. Mol Ther 2010, 18:1275-1283

80. Kuriyama N, Kuriyama H, Julin CM, Lamborn K, Israel MA: Pretreatment with protease is a useful experimental strategy for enhancing adenovirus-mediated cancer gene therapy. Hum Gene Ther 2000, 11:2219-2230.

81. McKee TD, Grandi P, Mok W, Alexandrakis G, Insin N, Zimmer JP, Bawendi MG, Boucher Y, Breakefield XO, Jain RK: Degradation of fibrillar collagen in a human melanoma xenograft improves the efficacy of an oncolytic herpes simplex virus vector. Cancer Res 2006, 66:2509-2513.

82. Netti PA, Berk DA, Swartz MA, Grodzinsky AJ, Jain RK: Role of extracellular matrix assembly in interstitial transport in solid tumors. Cancer Res 2000, 60:2497-2503.

83. Fujiwara S, Nawa A, Luo C, Kamakura M, Goshima F, Kondo C, Kiyono T, Kikkawa F, Nishiyama Y: Carrier cell-based delivery of replicationcompetent HSV-1 mutants enhances antitumor effect for ovarian cancer. Cancer Gene Ther 2011, 18:77-86.

84. Komarova S, Kawakami Y, Stoff-Khalili MA, Curiel DT, Pereboeva L: Mesenchymal progenitor cells as cellular vehicles for delivery of oncolytic adenoviruses. Mol Cancer Ther 2006, 5:755-766.

85. Thorne SH, Contag CH: Integrating the biological characteristics of oncolytic viruses and immune cells can optimize therapeutic benefits of cell-based delivery. Gene Ther 2008, 15:753-758.

86. Ong HT, Hasegawa K, Dietz AB, Russell SJ, Peng KW: Evaluation of T cells as carriers for systemic measles virotherapy in the presence of antiviral antibodies. Gene Ther 2007, 14:324-333.

87. Hakkarainen T, Sarkioja M, Lehenkari P, Miettinen S, Ylikomi T, Suuronen R, Desmond RA, Kanerva A, Hemminki A: Human mesenchymal stem cells lack tumor tropism but enhance the antitumor activity of oncolytic adenoviruses in orthotopic lung and breast tumors. Hum Gene Ther 2007, 18:627-641.

88. Stoff-Khalili MA, Rivera AA, Mathis JM, Banerjee NS, Moon AS, Hess A, Rocconi RP, Numnum TM, Everts M, Chow LT, et al: Mesenchymal stem cells as a vehicle for targeted delivery of CRAds to lung metastases of breast carcinoma. Breast Cancer Res Treat 2007, 105:157-167.

89. Coukos G, Makrigiannakis A, Kang EH, Caparelli D, Benjamin I, Kaiser LR, Rubin SC, Albelda SM, Molnar-Kimber KL: Use of carrier cells to deliver a replication-selective herpes simplex virus-1 mutant for the intraperitoneal therapy of epithelial ovarian cancer. Clin Cancer Res 1999, 5:1523-1537.
90. Power AT, Bell JC: Cell-based delivery of oncolytic viruses: a new strategic alliance for a biological strike against cancer. Mol Ther 2007, 15:660-665.

91. Hamada K, Desaki J, Nakagawa K, Zhang T, Shirakawa T, Gotoh A, Tagawa M: Carrier cell-mediated delivery of a replication-competent adenovirus for cancer gene therapy. Mol Ther 2007, 15:1121-1128.

92. lankov ID, Blechacz B, Liu C, Schmeckpeper JD, Tarara JE, Federspiel MJ, Caplice N, Russell SJ: Infected cell carriers: a new strategy for systemic delivery of oncolytic measles viruses in cancer virotherapy. Mol Ther 2007, 15:114-122.

93. Alcayaga-Miranda F, Cascallo M, Rojas JJ, Pastor J, Alemany R: Osteosarcoma cells as carriers to allow antitumor activity of canine oncolytic adenovirus in the presence of neutralizing antibodies. Cancer Gene Ther 2010, 17:792-802.

94. MacTavish H, Diallo JS, Huang B, Stanford M, Le Boeuf F, De Silva N, Cox J, Simmons JG, Guimond T, Falls T, et al: Enhancement of vaccinia virus based oncolysis with histone deacetylase inhibitors. PLoS One 2010, 5 e14462.

95. Advani SJ, Markert JM, Sood RF, Samuel S, Gillespie GY, Shao MY, Roizman B, Weichselbaum RR: Increased oncolytic efficacy for high-grade gliomas by optimal integration of ionizing radiation into the replicative cycle of HSV-1. Gene Ther 2011.

96. Le Boeuf F, Diallo JS, McCart JA, Thorne S, Falls T, Stanford M, Kanji F, Auer R, Brown CW, Lichty BD, et al: Synergistic interaction between oncolytic viruses augments tumor killing. Mol Ther 2010, 18:888-895.

97. Breitbach CJ, De Silva NS, Falls TJ, Aladl U, Evgin L, Paterson J, Sun YY, Roy DG, Rintoul JL, Daneshmand M, et al: Targeting tumor vasculature with an oncolytic virus. Mol Ther 2011, 19:886-894.

98. Hicklin DJ, Ellis LM: Role of the vascular endothelial growth factor pathway in tumor growth and angiogenesis. J Clin Oncol 2005, 23:1011-1027.

99. Guse K, Sloniecka M, Diaconu I, Ottolino-Perry K, Tang N, Ng C, Le Boeuf F, Bell JC, McCart JA, Ristimaki A, et al: Antiangiogenic arming of an oncolytic vaccinia virus enhances antitumor efficacy in renal cell cancer models. J Virol 2010, 84:856-866.

100. Frentzen A, Yu YA, Chen N, Zhang Q, Weibel S, Raab V, Szalay AA: AntiVEGF single-chain antibody GLAF-1 encoded by oncolytic vaccinia virus significantly enhances antitumor therapy. Proc Natl Acad Sci USA 2009, 106:12915-12920.

101. Qiu CW, Lin DG, Wang JQ, Li CY, Deng GZ: Expression and significance of PTEN and VEGF in canine mammary gland tumours. Vet Res Commun 2008, 32:463-472.

102. Platt SR, Scase TJ, Adams V, Wieczorek L, Miller J, Adamo F, Long S: Vascular endothelial growth factor expression in canine intracranial meningiomas and association with patient survival. J Vet Intern Med 2006, 20:663-668.

103. Al-Dissi AN, Haines DM, Singh B, Kidney BA: Immunohistochemical expression of vascular endothelial growth factor and vascular endothelial growth factor receptor-2 in canine simple mammary gland adenocarcinomas. Can Vet J 2010, 51:1109-1114.

104. Mederle O, Mederle N, Bocan EV, Ceausu R, Raica M: VEGF expression in dog mastocytoma. Rev Med Chir Soc Med Nat lasi 2010, 114:185-188.

105. Amorim RL, Pinczowski P, Neto RT, Rahal SC: Immunohistochemical evaluation of prostaglandin E2 and vascular endothelial growth factor in canine cutaneous mast cell tumours. Vet Comp Oncol 2010, 8:23-27.

106. de Queiroz GF, Dagli ML, Fukumasu H, Zavala AA, Matera JM: Vascular endothelial growth factor expression and microvascular density in soft tissue sarcomas in dogs. J Vet Diagn Invest 2010, 22:105-108.

107. Blackwood L, O'Shaughnessy PJ, Reid SW, Argyle DJ: E. coli nitroreductase/ CB1954: in vitro studies into a potential system for feline cancer gene therapy. Vet J 2001, 161:269-279.

108. Hlavaty J, Jandl G, Liszt M, Petznek H, Konig-Schuster M, Sedlak J, Egerbacher M, Weissenberger J, Salmons B, Gunzburg WH, Renner M: Comparative evaluation of preclinical in vivo models for the assessment of replicating retroviral vectors for the treatment of glioblastoma. $J$ Neurooncol 2011, 102:59-69.

109. Touchefeu Y, Vassaux G, Harrington KJ: Oncolytic viruses in radiation oncology. Radiother Oncol 2011, 99:262-270

110. Wennier ST, Liu J, McFadden G: Bugs and Drugs: Oncolytic Virotherapy in Combination with Chemotherapy. Curr Pharm Biotechnol 2011. 
111. Woo Y, Adusumilli PS, Fong Y: Advances in oncolytic viral therapy. Curr Opin Investig Drugs 2006, 7:549-559.

112. Vile $R$, Ando D, Kirn D: The oncolytic virotherapy treatment platform for cancer: unique biological and biosafety points to consider. Cancer Gene Ther 2002, 9:1062-1067.

113. Khanna C, Lindblad-Toh K, Vail D, London C, Bergman P, Barber L, Breen M, Kitchell B, McNeil E, Modiano JF, et al: The dog as a cancer model. Nat Biotechnol 2006, 24:1065-1066.

114. Vail DM, MacEwen EG: Spontaneously occurring tumors of companion animals as models for human cancer. Cancer Invest 2000, 18:781-792.

115. Hansen K, Khanna C: Spontaneous and genetically engineered animal models; use in preclinical cancer drug development. Eur J Cancer 2004, 40:858-880.

116. Genelhu MC, Cardoso SV, Gobbi H, Cassali GD: A comparative study between mixed-type tumours from human salivary and canine mammary glands. BMC Cancer 2007, 7:218.

117. Hayes HM Jr, Fraumeni JF Jr: Epidemiological features of canine renal neoplasms. Cancer Res 1977, 37:2553-2556.

118. Bukowski JA, Wartenberg D, Goldschmidt M: Environmental causes for sinonasal cancers in pet dogs, and their usefulness as sentinels of indoor cancer risk. J Toxicol Environ Health A 1998, 54:579-591.

119. Rivera P, von Euler H: Molecular biological aspects on canine and human mammary tumors. Vet Pathol 2011, 48:132-146.

120. Wildner O, Hoffmann D, Jogler C, Uberla K: Comparison of HSV-1 thymidine kinase-dependent and -independent inhibition of replicationcompetent adenoviral vectors by a panel of drugs. Cancer Gene Ther 2003, 10:791-802.

121. Hallden G, Hill R, Wang Y, Anand A, Liu TC, Lemoine NR, Francis J, Hawkins L, Kirn D: Novel immunocompetent murine tumor models for the assessment of replication-competent oncolytic adenovirus efficacy. Mol Ther 2003, 8:412-424.

122. Wang Y, Hallden G, Hill R, Anand A, Liu TC, Francis J, Brooks G, Lemoine N, Kirn D: E3 gene manipulations affect oncolytic adenovirus activity in immunocompetent tumor models. Nat Biotechnol 2003, 21:1328-1335.

123. Withrow SJ, Powers BE, Straw RC, Wilkins RM: Comparative aspects of osteosarcoma. Dog versus man. Clin Orthop Relat Res 1991, 159-168.

124. Lindblad-Toh K, Wade CM, Mikkelsen TS, Karlsson EK, Jaffe DB, Kamal M, Clamp M, Chang JL, Kulbokas EJ, Zody MC, et al: Genome sequence, comparative analysis and haplotype structure of the domestic dog. Nature 2005, 438:803-819.

doi:10.1186/1479-5876-10-3

Cite this article as: Patil et al:: Oncolytic virotherapy in veterinary medicine: current status and future prospects for canine patients. Journal of Translational Medicine 2012 10:3.

\section{Submit your next manuscript to BioMed Central and take full advantage of:}

- Convenient online submission

- Thorough peer review

- No space constraints or color figure charges

- Immediate publication on acceptance

- Inclusion in PubMed, CAS, Scopus and Google Scholar

- Research which is freely available for redistribution

Submit your manuscript at www.biomedcentral.com/submit
Biomed Central 